\title{
Endolymphatic irradiation in preparation for renal transplantation: a 26-year's follow-up
}

Renal Transplant Unit, Hospital das Clínicas, Universidade de São Paulo. Division of Immunology, Universidade Federal de São Paulo/Escola Paulista de Medicina, São Paulo, Brazil

\begin{abstract}
Objective: The aim of the present study was to analyze the long-term evolution of patients submitted to endolymphatic irradiation as a pre-transplant preparation. Setting: Referral center of university hospital. Design: Case-control study. Main outcomes measures: The study was designed to evaluate the incidence of rejection, kidney loss, leukopenia, infection, and graft survival in the group treated (group 1) prior to surgery, compared to a control group (group 2) composed of patients under identical clinical conditions (sex, age, type of donor, immunosuppressive therapy and time of transplant) that did not undergo treatment preparation. Patients: Patients were selected from amongst transplantation candidates on a long-term waiting list, some with a high level of antibodies against panel. The control group was chosen from amongst recently transplanted patients. Patients in the treated group received lipoiodine containing ${ }_{131}$ with specific activity ranging between 4 and $6 \mathrm{mCu} / \mathrm{ml}$. Results: A significant difference between the two groups was found with regard to the incidence of rejection crises $(21.0 \%$ in group 1 and $73.6 \%$ in group $2 ; P=0.003)$, and the maintenance dose of azathioprine (smaller in group $1 ; \mathrm{P}<0.01)$. As to kidney graft loss due to rejection, a tendency to significance could be identified (10.5\% in group 1 and $42.1 \%$ in group 2; $P=0.063$ ); however, the difference was not significant between the two groups in terms of reversibility of rejection episodes during the first 60 post-transplant days. Conclusions: The authors concluded that this method, besides being relatively innocuous (there was no compromising of either the thyroid gland or of gonad function and there was no increase in tumor incidence), has an extended immunosuppressive effect, and can be indicated for cadaveric renal allograft recipients, especially those showing high panel reactivity.
\end{abstract}

UNITERMS: Kidney transplantation. Endolymphatic irradiation. Immunosuppression

\section{INTRODUCTION}

$\mathrm{T}$ he immunosuppressive effects of irradiation are well known, but its use in clinical transplantation has been relegated to a secondary level. Firstly, the favorable results obtained with drugs such as

\author{
Address for correspondence \\ Maria Margarida Galvão \\ Unidade de Transplante Renal \\ Hospital das Clínicas da FMUSP \\ Av. Dr. Enéas de Carvalho Aguiar, 255 \\ São Paulo/SP - Brasil - CEP 05403-010
}

azathioprine and prednisone, the introduction of cyclosporine as an immunosuppressive agent, and the use of monoclonal antibodies, and secondly, the frequently lethal outcome of high doses of full-body irradiation, may be responsible for the lack of interest in this method. Nevertheless, the development of a safe and effective irradiation method could prove beneficial to presensitized patients. In recent years, a number of studies have been carried out using total lymphoid irradiation (TLI) in an attempt to eliminate natural antibodies to xenografts. ${ }^{(1)}$

From 1967 to 197219 patients with chronic renal failure were submitted to lipoiodine ${ }^{131} \mathrm{I}$ endolymphatic irradiation (ELI) prior to renal transplantation. In 1975 we reported on the method and the immunosuppressive 
results in early post-transplant stages. ${ }^{(2)}$ Following endolymphatic irradiation, a significant decrease in $\mathrm{T}$ and B lymphocytes could be observed, lasting for an average period of 30 days.

The purpose of the present study was to analyse recent data on these same 19 patients and to compare survival rates and incidental side effects with a nonirradiated control group.

\section{METHODS}

Group 1: We evaluated 19 transplantation patients who received kidney grafts between 1967 and 1972, and who were submitted to endolymphatic irradiation with ${ }^{131} \mathrm{I}$ as a previous immunosuppressive measure.

On average, patients were irradiated 53 days prior to renal transplantation (range 10 to 224 days). In one case irradiation was performed 135 days after transplantation to treat a rejection crisis. One patient was irradiated prior to a third renal graft implantation. Besides irradiation the patients received standard immunosuppressive treatment with azathioprine and prednisone.

We used an ultrafluid solution of lipoiodine containing ${ }^{131} \mathrm{I}$ which was prepared according to the substitution technique, with specific activity ranging from 4 to $6 \mathrm{mCu} / \mathrm{ml}$. The solution was innoculated via instep (a total of $10 \mathrm{ml}$ ) and the lymph nodes were visualized by injecting alphazurine at $11 \%$.

All patients had their thyroid gland previously blocked up with iodide administered orally (a lugol solution, starting the day before irradiation and maintained for a few days afterwards) or parenterally (intravenous injection of $10 \%$ sodium iodide).

Group 2: comprised 19 patients randomly selected from amongst transplant recipients, matched to each patient from the irradiated group in terms of time of transplant and type of donor. The age ranged from 15 to 52 years.

The two groups were comparable regarding age, sex, type of donor and type of primary disease (Table 1).
In both groups we analyzed: 1 - incidence and reversibility of rejection crises during the first 60 posttransplant days; 2 - incidence of leukopenia; 3 - graft and patient survival rates, and graft loss. Patient and graft survival were analyzed by the Kaplan and Meier method (actuarial survival). Data were analyzed statistically by non-parametric tests (chi-square and Fisher's exact test), with the level of significance set at $\mathrm{P}<0.05$.

Late evaluation of thyroid function was performed on nine patients from the irradiated group by $\mathrm{T} 4$ measurement and by the iodine uptake test. Seven male patients underwent a spermogram.

\section{RESULTS}

\section{Incidence of rejection during the first 60 days after operation}

The number of acute rejection episodes during the early post-transplant period was significantly smaller in group 1 ( $21 \%$ vs $73.6 \% ; \mathrm{P}=0.003)$. A complete reversal occurred in all cases (Table 2).

\section{Leukopenia}

Ten patients in the irradiated group $(52.6 \%)$ had leukopenia (leukocyte count $<3.500 / \mathrm{mm}^{3}$ ) at an early posttransplant stage. Of these, only one showed persistent leukopenia throughout the evolution, and did not tolerate the usual dose of azathioprine. Two other patients had a tendency to develop leukopenia in a later stage of the follow-up. Two patients presented a decrease in leukocytes, one and seven years after transplantation, respectively, which was reversed with reduction of azathioprine. Later on the dose was increased again and was well tolerated. Seven other patients were leukopenic at some point of the evolution.

In group 2 the incidence of leukopenia during the first 60 days after surgery was $15.7 \%$ (three patients). The remaining patients did not have leukopenia.

Table 1

Comparison of features of the two groups: irradiated patients (group 1) and non-irradiated patients (group 2)

\begin{tabular}{cccc}
\hline Parameter & Group 1 $(\mathbf{n}=\mathbf{1 9})$ & Group 2 $(\mathbf{n}=\mathbf{1 9})$ & p value \\
\hline age & 14 to $52(31.2 \pm 11.1)$ & 23 to $52(36.4 \pm 8.3)$ & NS \\
male/female & $10 / 9$ & $15 / 4$ & NS \\
living related donor & 8 & 10 & NS \\
\hline
\end{tabular}


Table 2

Evolution data for both groups

\begin{tabular}{cccc}
\hline Events & Group 1 $(\mathbf{n}=\mathbf{1 9})$ & Group 2 $(\mathbf{n = 1 9 )}$ & p value \\
\hline early acute rejections & $4(21 \%)$ & $14(73.6 \%)$ & 0.003 \\
reversed episodes & $4 / 4(100 \%)$ & $12 / 14(85.7 \%)$ & NS \\
leukopenia & $10(52.6 \%)$ & $3(15.7 \%)$ & 0.038 \\
graft loss & $2(10.5 \%)$ & $8(42.1 \%)$ & 0.063 \\
infection incidence & $11(57.8 \%)$ & $8(42.1 \%)$ & NS \\
\hline
\end{tabular}

\section{Patient and graft survival rates (figures 1 and 2)}

Group 1: three patients died during the first year $(15.7 \%)$ due to different causes but all had a functioning graft. Amongst the 16 patients who survived more than one year, two died from chronic rejection and eight had functional grafts until the time of death. Six patients are still alive and their renal function is preserved 21 to 26 years after transplantation; three of them are cadaveric transplant recipients, and one received a third graft following irradiation.

Group 2: eight deaths occurred during the first year $(42.1 \%)$, two of them during rejection. Of the remaining 11 patients who survived more than one year, six lost their graft or died with chronic rejection, three died with their renal function preserved, and two are still alive with functioning grafts 22 and 26 years after receiving kidney allografts, from a cadaveric donor and from a living related (sibling) donor respectively.

\section{Sexual function}

Two patients conceived following transplantation and successfully carried pregnancy to full term. One patient gave birth prematurely to a normal child who died of hyaline membrane. The other child showed no abnormalities. Spermograms performed four to eight years after irradiation indicated azoospermia in four patients and oligoasthenospermia in three.

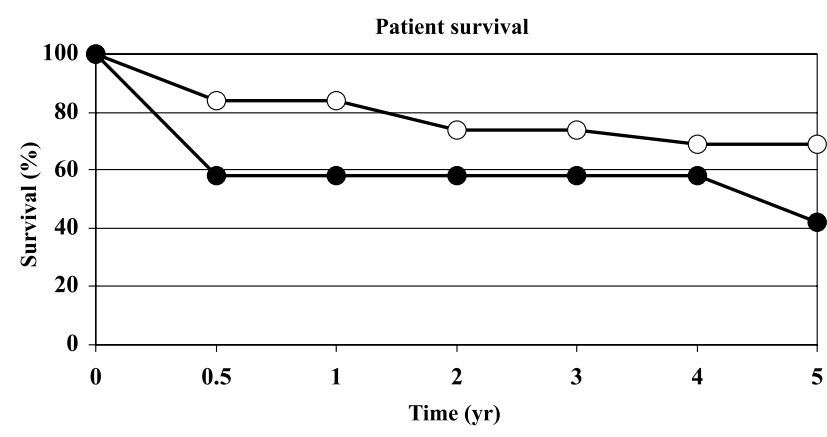

Figure 1. Actuarial patient survival: (O) group 1 and $(\bullet)$ group 2.

\section{Thyroid function}

Data collected from the nine patients submitted to the above tests revealed normal thyroid function.

\section{Tumor incidence}

In group 1, one patient had chronic myeloid leukemia which was diagnosed two years and four months after transplantation. Two other patients had a basocellular and spinocellular carcinoma of the skin, respectively, that was treated surgically. In group 2, two patients had carcinoma of the skin and one died from dissemination of the tumor.

\section{Incidence of infection}

Different types of infections were identified in 11 patients from group 1. Those who survived for a longer time presented higher rates of infection. In group 2, eight patients had some kind of infection during their clinical evolution.

\section{Immunosuppression}

Azathioprine doses ( $\mathrm{mg} / \mathrm{kg}$ body weight) were significantly $(\mathrm{P}<0.01)$ lower in group $1(0.6$ to $3 \mathrm{mg} / \mathrm{kg}$ daily - average 1.57 ) than in group 2 (1.2 to $3 \mathrm{mg} / \mathrm{kg}$ daily - average 2.3). The maintenance dose of prednisone was the same in both groups. Current doses of azathioprine

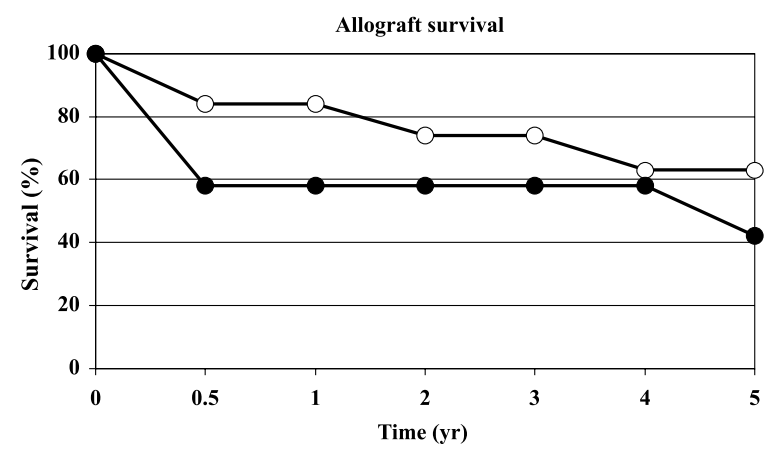

Figure 2. Actuarial graft survival: $(\mathrm{O})$ group 1 and $(\bullet)$ group 2 . 
given to the six patients still alive in group 1 range from 1.2 to $2 \mathrm{mg} / \mathrm{kg} /$ day (average $1.52 \pm 0.39$ ). In group 2 , maintenance doses are 2.4 and $2.2 \mathrm{mg} / \mathrm{kg} / \mathrm{day}$, respectively, for the two patients alive 22 and 26 years posttransplantation.

\section{DISCUSSION}

The incidence of rejection during the early posttransplant stage was significantly lower in the irradiated group than in the control group, and complete reversal occurred in all cases. Graft losses due to chronic rejection occurred at a later stage as a result of abandonment of the immunosuppressive therapy.

In group 2, the number of graft losses due to rejection was remarkably higher: two during the early stage and eight during a later stage after transplantation (Table 2).

Birkeland et al. ${ }^{(3)}$ found a depressed immune response in six patients submitted to endolymphatic irradiation with ${ }^{198} \mathrm{Au}$ and ${ }^{32} \mathrm{P}$, evaluated by mixed lymphocyte culture and stimulation with PHA. Reactivity in the mixed culture was reduced to less than $30 \%$ of the pre TLI values, remaining at those levels for six months and partially increasing thereafter. ${ }^{(4)}$ Other investigators employing TLI identified an inhibition of splenocyte proliferation in response to a mitogen, with absence of IL-2 production and expression of IL-2 receptors. ${ }^{(5,6)}$ The use of TLI caused a significant decrease in absolute $\mathrm{T}$ helper numbers with rapid recovery of cytotoxic and suppressor cells. . $^{(1,5)}$

We observed significant $\mathrm{T}$ and $\mathrm{B}$ lymphocyte depletion in peripheral blood during the first 30 days after irradiation with ${ }^{131} \mathrm{I} .^{(2)}$ Analogous results were obtained after TLI. Although total counts indicated some recovery, $\mathrm{T}$ cells remained reduced in number for many years. ${ }^{(1)}$

Survival rates were significantly higher in group 1. We could also observe a significant difference when comparing incidence of rejection during the first 60 posttransplant days and loss of graft due to chronic rejection (Table 2). Results obtained with TLI have revealed a significant increase in survival rates both in experimental ${ }^{(6,7)}$ and clinical studies. ${ }^{(8,9)}$

In one patient, endolymphatic irradiation was performed after transplantation with the purpose of controlling a rejection crisis that did not respond to the standard therapy available at that time. Favorable results were also obtained by Salter et al. with TLI in the control of early acute rejection or recurrent heart rejection in 19 patients. ${ }^{(10)}$
An interesting finding of this clinical trial was that low doses of immunosuppressive drugs are sufficient for the maintenance therapy of long-term survivors.

The incidence of leukopenia in group 1 was high $(52.6 \%)$. However, neither early leukopenia nor reduced doses of azathioprine interfered with the function or survival rate of the graft.

There were no side effects of irradiation on radiosensitive tissues and extralymphatic organs close to strongly irradiated lymphoid masses, due to the predominant emission of beta particles, which have a poor capacity for penetration into soft tissues. This makes the irradiation dose highly selective and harmless to underlying structures. ${ }^{(11)}$ Uptake by other organs through hematogenic dissemination was extremely low and nonsignificant; no effect of irradiation could be detected. ${ }^{(12)}$ Fixation to the thyroid is very poor, and can be further minimized by previous blockage of the gland with sodium iodide.

Irradiation of the pelvic organs was also found to be non-significant. A normal course of pregnancy is possible after irradiation, as in our two cases reported above. In parallel, spermogram results in the seven cases investigated did not differ from those usually found in post-transplant non-irradiated patients. The uremic condition damages the germ cells, but on the other hand, successful transplantation leads to moderate, though not absolute, histologic recovery. However, oligoasthenospermia usually persists. ${ }^{(13)}$

Hematic irradiation is almost nonexistent, and the bone marrow seems not to be affected. When examining bone marrow biopsies, Birkland et al. ${ }^{(3)}$ detected nonsignificant slight alterations in white and red blood cell precursors, lymphocytes and plasma cells, as indicated by the paired $\mathrm{T}$ test. A potentiating toxic effect of azathioprine on bone marrow probably occurs. This could explain the high incidence of leukopenia (52.6\%) among our post-transplant patients, whereas during the pretransplant observation period, before institution of the immunosuppressive therapy, the same patients did not experience a significant leukocyte depletion. ${ }^{(2)}$

In view of the consistent data obtained in both experimental and clinical studies, we conclude that irradiation is harmless and highly selective for lymph nodes. There seems to be no doubt as to its effect on the depression of the immune response. ${ }^{(1,3,5,14,15)}$

Galvão et al., ${ }^{(2)}$ investigating delayed type hypersensitivity pre- and post-irradiation, found that in five out of six patients previously showing positive results (two for trichophytin, two for candidin and two for DNCBdinitrochlorobenzene), the response became negative after ELI, suggesting that the immunological memory can, at least transiently, be abolished by endolymphatic irradiation. 


\section{CONCLUSION}

The results obtained in this retrospective study were encouraging, suggesting that this method is worth being submitted to a more rigorous and detailed evaluation, conducted in a prospective and controlled manner. Its indication for cadaveric renal recipients with high reactivity against panel should be considered.

\section{Resumo}

Objetivo: Analisar a evolução a longo prazo de pacientes que receberam irradiação endolinfática como preparo pré-transplante. O estudo avaliou a incidência de rejeição, perda de rim, leucopenia, infecções e a sobrevida do enxerto no grupo tratado (grupo 1) em comparação com o grupo controle (grupo 2) que se constituiu de pacientes em iguais condições clínicas (sexo, idade, tipo de doador, terapia imunossupressora e tempo de transplante) que não receberam o preparo. Local: Centro de referência. Tipo de estudo: Estudo caso-controle. Participantes: Os pacientes foram selecionados entre aqueles em lista de espera para transplante a longo prazo, alguns dos quais com alto nível de anticorpos contra painel. O grupo controle foi escolhido entre os pacientes transplantados na época. Os pacientes do grupo tratado receberam lipiodol contendo ${ }^{131}$ I com atividade específica variando entre 4 e $6 \mathrm{mCu} / \mathrm{ml}$. Resultados: Foi encontrada diferença significativa entre os dois grupos com relação à incidência de crise de rejeição $(21 \%$ no grupo 1 e $73,6 \%$ no grupo $2 ; \mathrm{P}=0,003)$ e manutenção da dosagem de azatioprina (menor no grupo $1 ; \mathrm{P}<0,01$ ). Quanto à perda de rim com rejeição, verificou-se uma tendência à significância $(10,5 \%$ no grupo 1 e $42,1 \%$ no grupo 2 : $P=0,063)$; todavia a diferença entre os dois grupos não foi significativa no que diz respeito à reversibilidade dos episódios de rejeição durante os primeiros 60 dias pós-transplante. Conclusões: Os autores concluem que o método, além de ser relativamente inócuo (não houve comprometimento da função tireoidiana nem da função gonadal, nem houve aumento na incidência de tumores), tem um efeito imunossupressor prolongado, podendo ser usado em receptores de rim de cadáver, especialmente aqueles que tenham alta reatividade em painel.

\section{REFERENCES}

1. Halperin, EC, Knechtle, SJ, Harland RC, Yamaguchi Y, Sontag M, Bollinger RR. Irradiation for xenogenic transplantation. Radiother-Oncol 1990; 18:29-37.

2. Galvão MM, Sabbaga E, Peixinho ZF, Musatti CC, Mendes NF. Immunosuppressive effect of intralymphatic irradiation. Allergol Immunopathol 1975; 3:299-308.

3. Birckeland SA, Moesner J, Kalnaes O, Jensen TS. Endolymphatic irradiation with ${ }^{198} \mathrm{Au}$ and ${ }^{32} \mathrm{P}$ immunosuppression in renal transplantation. Radiation Res 1976; 65:371-85.

4. Saper V, Chow D, Engleman ED, Hoppe RT, Levin B, Collins G, Strober S. Clinical and immunological studies of cadaveric renal transplant recipients given total lymphoid irradiation and maintained on low-dose prednisone. Transplantation. 1988; 45:540-6.

5. Ye ZX, Becker GC, Field EH. Mechanisms of total lymphoid irradiation-induced immunosuppression. Transplantation. 1990; 50:839-45.

6. Thomas J, Alquaisi M, Cunningham P, Carver M, Rebellato L, Gross U, Patselas T, Araneda D, Thomas F. The development of a post-transplant TLI treatment strategy that promotes organ allograft acceptance without chronic immunosuppression. Transplantation 1992; 53:247-58.

7. Woodley SL, Gurley KE, Hoffmann SL, Nicolls MR, Hagberg R, Clayberger C, Holm B, Wang X, Hall BM, Strober S. Induction of tolerance to heart allografts in rats using post-transplant total lymphoid irradiation and anti-T cell antibodies. Transplantation 1993; 56:1443-7.

8. Myburg JA, Meyers AM, Margohus L, Thomson PD, Botha JR, Lakier R, Smit JA, Stark JH. Total lymphoid irradiation in clinical renal transplantation: results in 73 patients. Transplant Proc 1991; 23:2033-4.

9. Strober S, Dhillon M, Schubert M, Holm B, Engleman E, Benike C, Hoppe R, Sibley R, Myburgh JA, Collins G, Levin $B$. Acquired immune tolerance to cadaveric renal allografts: a study of three patients treated with total lymphoid irradiation. New Engl J Med 1989; 321:28-33.

10. Salter MM, Kirklin JK, Dourge RC, Naftel DC, WhiteWilliams C, Tarkka M, Waits E, Bucy RP. Total lymphoid irradiation in the treatment of early or recurrent heart rejection. J Heart Lung Transplant 1992; 11:902-11.

11. Peters PE, Weissler H. Current status of endolymphatic therapy with radionuclides. Lymphology 1974; 7:49-52.

12. Irino S, Tanji T, Uno J, Oka A. Experimental studies of the endolymphatic radiotherapy. Acta Med Okayama 1974; 28: 59-67.

13. Rodrigues NN, Pecoraro G, Sabbaga E. Spermatogenesis before and after transplant. Int J Fertil 1980; 25:131-3.

14. Szabó G, Magyar L, Balint J. Prolongation of skin homograft survival by local intralymphatic radioisotope injections. Experientia 1968; 24:70-1.

15. Wheeler JR, White WF, Calne RY. Selective lymphopenia by use of intralymphatic ${ }^{198} \mathrm{Au}$ and splenectomy. Immunosuppressive action on rejection of canine renal homografts. Br Med J 1965; 2:339-42. 